\title{
TUBERCULOSIS DETERMINED BY MYCOBACTERIUM BOVIS IN CAPTIVE WATERBUCKS (KOBUS ELLIPSIPRYMNUS) IN SÃO PAULO, BRAZIL
}

\author{
V.C.M. Rocha ${ }^{1}$, S.H.R. Corrêa ${ }^{2}$, E.M.D. Oliveira ${ }^{3}$, C.A.R. Rodriguez $^{1}$, J.D. Fedullo ${ }^{2}$, M. Matrone ${ }^{1}$ A. Setzer $^{2}$, C.Y. Ikuta ${ }^{1}$, \\ M.P. Vejarano ${ }^{1}$, S.M. Figueiredo ${ }^{3}$, J.S. Ferreira Neto ${ }^{1}$
}

${ }^{1}$ Faculdade de Medicina Veterinária e Zootecnia, Universidade de São Paulo, São Paulo, SP, Brasil; ${ }^{2}$ Fundação Parque Zoológico de São Paulo, São Paulo, SP, Brasil; ${ }^{3}$ Escola de Medicina Veterinária, Universidade Federal da Bahia, Salvador, BA, Brasil.

Submitted: April 22, 2010; Returned to authors for corrections: June 07, 2010; Approved: November 04, 2010.

\begin{abstract}
Two waterbucks from São Paulo Zoo Foundation exhibited respiratory symptoms in July 2004. After euthanasia, granulommas in lungs and mediastinic lymph nodes were observed. Acid-fast bacilli isolated were identified as Mycobacterium bovis spoligotype SB0121 by PRA and spoligotyping. They were born and kept in the same enclosure with the same group, without any contact to other species housed in the zoo. This is the first detailed description of M. bovis infection in Kobus ellipsiprymnus.
\end{abstract}

Key words: Tuberculosis, Mycobacterium bovis, Kobus ellipsiprymnus, Waterbuck, Zoo.

Mycobacterium bovis is the etiologic agent of zoonotic tuberculosis. Although its main host is the domestic bovine, it can also infect various domestic and wild animals.

Infections with various mycobacteria species have been reported in captive animals from zoos and parks. Tuberculosis is one of the oldest and most frequent problems in zoos in the USA and Europe (9). Up to the 60's, tuberculosis caused by Mycobacterium bovis or M. tuberculosis has led to the loss of more than $40 \%$ of some zoo collections (12).

Mycobacterium bovis has already been reported in a large number of different captive species, including threatened ones (8). An outbreak of M. bovis in the Audubon Zoological Garden, New Orleans, caused the death of four white rhinoceroses (Ceratotherium simum) and two white colobus monkeys (Colobus guereza caudatus) (13). In the Dublin Zoo, an outbreak of $M$. bovis resulted in the infection of one Mayotte lemur (Lemur mayottensis mayottensis), one liontailed macaque (Macacus silenus), one patas monkey (Erythrocebus patas) and one siamang (Symphalangus syndactylus) (15). If the M. bovis is introduced into a zoo it can spread to other species.

At the beginning of July 2004, a couple of Waterbucks (Kobus ellipsiprymnus) exhibited an important set of respiratory symptoms with cough that became chronic. They were housed in an outdoor enclosure with three other animals of the same species at the Zoo Safari, which is part of the facility belonging to the São Paulo Zoo Foundation (SPZF), São Paulo, Brazil. The diagnostic hypothesis was tuberculosis and these two animals were euthanized with anesthetics in March 2005. 
During the male's necropsy, macroscopic lesions were observed in the lungs and mediastinic lymph nodes in the thoracic cavity. These lesions were spherical, whitish and had a diameter from 1.0 to $7.0 \mathrm{~cm}$, suggesting granulommas. The mediastinic lymph nodes were enlarged and solid. Similar lesions were observed in the female carcass.

Lesions fragments from both animals were sampled for histopathological and bacteriological examinations. Representative fragments were fixed in $10 \%$ buffered formalin and embedded in paraffin for routine histological procedure. Cuts of $5 \mu \mathrm{m}$ were obtained and stained according to hematoxilin-eosin technique. The microscopic exams confirmed granulommas with necrotic material rounded by cellular remains with peripheral giant cells, all surrounded by mononuclear infiltrate.

Samples of lungs and mediastinic lymph nodes were decontaminated with hexadecylpyridinium chloride (HPC) (1). After 30 days of incubation at $37^{\circ} \mathrm{C}$ in the Stonebrink medium, acid-fast bacilli tested positive by the Ziehl-Neelsen staining were isolated from samples of both waterbucks. All isolates were classified as Mycobacterium tuberculosis complex by PRA (Polymerase Chain Reaction Restriction Analysis) (14) and identified as Mycobacterium bovis spoligotype SB0121 (nomenclature adopted from www.mbovis.org) by Spoligotyping method (6).

Although the $M$. bovis infection has been reported in animals of the Kobus genus, specifically in free-living Kobus leche (2), this is the first detailed description of a M. bovis infection in Kobus ellipsiprymnus (according to the following databases: Google Scholar, Scopus Info, Pubmed/Medline, BioOne Online Journals, Science Direct and Wiley Interscience, accessed at February 2010).

The clinical aspects and the results of necropsy and laboratory exams suggest the animals developed lung disease due to inhaling aerosols containing the etiologic agent of zoonotic tuberculosis.

The same spoligotype SB0121 infecting both waterbucks suggests a single source of infection for the group of animals. This pattern is one of the most common spoligotypes and it has been associated to cattle, goat, deer and wild boar $(3,11)$. It has been isolated from bovines in Portugal, Spain, France (3), Italy, Great Britain (11), Netherlands, Belgium (5) and also in Brazil (10).

The infected waterbucks, and also their parents, were born in the SPZF and were kept in the same enclosure with the same animal group, without any contact to other species housed in the Zoo Safari. There was no introduction of new animals in the group of waterbucks during the last four generations. It was impossible to detect the source of the infection.

After the tuberculosis diagnosis, the remaining three contact animals were euthanized. The carcasses were buried and the enclosure was disinfected according to the Manual of the National Program for Control and Eradication of Brucellosis and Tuberculosis (7).

\section{ACKNOWLEDGEMENTS}

The authors wish to thank FAPESP for financial support.

\section{REFERENCES}

1. Ambrosio, S.R.; Oliveira, E.M.D.; Rodriguez, C.A.R.; Ferreira Neto, J.S.; Amaku, M. (2008). Comparison of three decontamination methods for Mycobacterium bovis isolation. Braz. J.. Microbiol. 39 (2). 241-244.

2. Clancey, J.K. (1977). The incidence of tuberculosis in lechwe (Marsh Antelope). Tubercle. 58 (3). 151-156.

3. Duarte, E.L.; Domingos, M.; Amado, A.; Botelho, A. (2008). Spoligotype diversity of Mycobacterium bovis and Mycobacterium caprae animal isolates. Vet. Microbiol. 130 (3-4). 415-421.

4. Grange, J.M.; Collins C.H. (1996). Bovine tuberculosis: reservoirs and sources of infection. Lett. Appl. Microbiol. 23 (3). 203-204.

5. Haddad, N.; Ostyn, A.; Karoui, C.; Masselot, M.; Thorel, M.F.; Hughes, S.L.; Inwald, J.; Hewinson, R. G.; Durand B. (2001). Spoligotype diversity of Mycobacterium bovis strains isolated in France from 1979 to 2000. J. Clin. Microbiol. 39 (10). 3623-3632.

6. Kamerbeek, J.; Schouls, L.; Kolk, A.; Van Agterveld, M.; Van Soolingen, D.; Kuijper, S.; Bunschotern, A.; Molhuizen, H.; Shaw, R.; 
Goyal, M.; Van Embden, J. (1997). Simultaneous detection and strain differentiation of Mycobacterium tuberculosis for diagnosis and epidemiology. J. Clin. Microbiol. 35 (4). 907-914.

7. Lage, A.P.; Roxo, E.; Müller, E.; Poester, F.; Cavalléro, J.C.M.; Ferreira Neto, J.S.; Mota, P.M.P.C.; Gonçalves, V.S.P. (2006). Programa Nacional de Controle e Erradicação da Brucelose e da Tuberculose Animal (PNCEBT). Manual Técnico. Ministério da Agricultura, Pecuária e Abastecimento, Brasília.

8. de Lisle, G.W.; Mackintosh, C.G.; Bengis, R.G. (2001). Mycobacterium bovis in free-living and captive wildlife, including farmed deer. Rev. Sci. Tech. 20 (1). 86-111.

9. Montali, R.J.; Mikota, S.K.; Cheng, L.I. (2001). Mycobacterium tuberculosis in zoos and wildlife species. Rev. Sci. Tech. 20 (1). 291303.

10. Rodriguez, C.A.R.; Zumárraga, M.J; Oliveira, E.M.D.; Cataldi, A.A.; Romano, M.I.; Otto, H.H.; Bonafé, V.L.; Ferreira Neto, J.S. (2004). Caracterização molecular de isolados de Mycobacterium bovis do Estado de São Paulo Brasil, utilizando a técnica de Soligotyping. Arq. Inst. Biol. 71 (3). 277-282.
11. Rodríguez, S.; Romero, B.; Bezos, J.; de Juan, L.; Álvarez, J.; Castellanos, E.; Moya, N.; Lozano, F.; González, S.; Sáez-Llorente, J.L.; Mateos, A.; Domínguez, L.; Aranaz, A. (2010). High spoligotype diversity within a Mycobacterium bovis population: Clues to understanding the demography of the pathogen in Europe. Vet. Microbiol. 141 (1-2). 89-95.

12. Ruch, T.C. (1959). Diseases of laboratory primates. W.B. Saunders Co., Philadelphia, Pennsylvania.

13. Stetter, M.D.; Mikota, S.K.; Gutter, A.F.; Monterroso, E.R.; Dalovisio, J.R.; Degraw, C.; Farley, T. 1995. Epizootic of Mycobacterium bovis in a zoologic park. J. Am. Vet. Med. Assoc. 207 (12). 1618-1621.

14. Telenti, A.; Marchesi, F.; Balz, M.; Bally, F.; Böttger, E.C.; Bodmer, T. (1993). Rapid identification of mycobacteria to the species level by polymerase chain reaction and restriction enzyme analysis. J. Clin. Microbiol. 31 (2). 175-178.

15. Wilson, P.; Weavers, E.; West, B.; Taylor, M.; Kavanagh, J.; Jones, P. (1984). Mycobacterium bovis infection in primates in Dublin zoo: epidemiological aspects and implications for management. Lab. Anim. 18 (4). 383-387. 